\title{
MUTATIONAL REPLACEMENT OF METHIONINE BY ARGININE IN THE S; SUBSTRATE BINDING SITE OF YEAST CARBOXYPEPTIDASE
}

\author{
by \\ LENE M. BECH, JOHN NIELSEN"), JAKOB R. WINTHER, \\ MORTEN C. KIELLAND-BRANDT ${ }^{2)}$ and KLAUS BREDDAM \\ Department of Chemistry, Carlsberg Laboratory, \\ Gamle Carlsberg Vej 10, DK-2500 Copenhagen Valby \\ " Department of Chemistry, H.C. Ørsted Institute, \\ Universitetsparken 5, DK-2100 Copenhagen $\varnothing$ \\ 2) Department of Physiology, Carlsberg Laboratory, \\ Gamle Carlsberg Vej 10, DK-2500 Copenhagen Valby
}

Keywords: Carboxypeptidase Y, binding sites, protein engineering, site-directed
mutagenesis, chemical modification, substrate specificity, kinetics

Alkylation of Met-398 in the $\mathrm{S}_{1}$ binding site of carboxypeptidase $\mathrm{Y}$ drastically reduces $\mathrm{k}_{\mathrm{cat}}$ for hydrolysis of peptides, presumably due to introduction of a positively charged sulfonium ion. In the present work a positive charge has been introduced by means of site-directed mutagenesis, exchanging Met-398 with the cationic arginyl residue. The mutagenesis was carried out in bacteriophage $\mathrm{M} 13$ on a subcloned fragment of $P R C 1$, the structural gene for carboxypeptidase $\mathrm{Y}$, using an oligonucleotide containing the desired mutation as primer for secondary strand synthesis in vitro. A clone was identified in which codon 398 of $P R C 1$ (ATG) had been changed to AGG, and the mutated sequence was reintroduced into the original $P R C I$ gene context. The resulting plasmid was used to transform a yeast strain, carrying a deletion at the $p r c l$ locus and the mutant enzyme was isolated by affinity chromatography. The $\mathrm{k}_{\text {cat }}$ values for the hydrolysis of $\mathrm{N}$-blocked dipeptide substrates with varying groups in the $P_{i}$ position were equally low as for the alkylated Met-398 derivatives, consistent with the expected effects of a positive charge in position 398 . The kinetic parameters for the hydrolysis of ester and amide substrates were similar to those obtained with the enzyme alkylated with iodoacetamide.

Abbreviations: Arg-398-CPD-Y = CPD-Y with an arginyl residue at position 398; CPD-Y = carboxypeptidase $\mathrm{Y}$; EDTA $=$ ethylenediamine tetraacetic acid, sodium salt; FA = furylacryloyl; Hepes = N-2-hydroxyethylpiperazine$\mathrm{N}$-2-ethane sulfonic acid; HPLC $=$ high performance liquid chromatography; IAA-CPD-Y = CPD-Y modified with iodoacetamide; Mes $=2-(\mathrm{N}$-morpholino)ethane sulfonic acid; Leu-398-CPD-Y $=\mathrm{CPD}-\mathrm{Y}$ with a leucyl residue at position 398: $\mathrm{PAB}-\mathrm{CPD}-\mathrm{Y}=\mathrm{CPD}-\mathrm{Y}$ modified with phenacylbromide; $\mathrm{SDS}=$ sodium dodecylsulfate; $\mathrm{SSC}=0.15$ $\mathrm{M}-\mathrm{NaCl}, 0.015 \mathrm{M}$-sodium citrate. Abbreviations of peptides are according to the guidelines of IUPAC-IUB Commision on Biochemical Nomenclature. The binding site notation for the enzymes is that of SCHECHTER and BERGER (8). Accordingly, the binding site for the C-terminal amino acid residue of the substrate is denoted $\mathrm{S}_{1}^{\prime}$ and those for the amino acid residues in the amino-terminal direction away from the scissile bond are denoted $S_{1}, S_{2}, \ldots, S_{n}$. Amino acids in the substrates are referred to as $P_{k}, P_{2}, \ldots, P_{n}$ and $P_{1}^{\prime}$ in correspondence with the binding site. 


\section{INTRODUCTION}

Carboxypeptidase $Y$ from yeast (CPD-Y) exhibits a preference for hydrophobic amino acid side-chains in the $P_{1}^{\prime}$ position of peptide substrates, suggesting that the corresponding binding site, $S_{1}^{\prime}$, is composed of primarily hydrophobic amino acid residues (2). Exchange of Met398 in this region with a leucyl residue, by means of site-directed mutagenesis of the structural gene for the enzyme resulted in an increased affinity for substrates with hydrophobic and bulky leaving groups, in accordance with a leucyl residue being smaller and more hydrophobic than a methionyl residue (14).

Chemical modifications of Met-398 with iadoacetamide, phenacylbromide or other alkylating reagents all caused drastic decreases in $\mathrm{k}_{\mathrm{cat}}$ for the hydrolysis of peptides, regardless of the bulkiness of the reagent. Thus, it is possible that the positive charge of the methionyl sulfonium ion resulting from the alkylations of the enzyme is responsible for the low $\mathbf{k}_{\text {cat }}$ values of these derivatives towards peptide substrates. In the present paper this postulated effect of introduction of a positive charge in the $S$; binding site has been investigated by exchange of Met-398 with an arginyl residue.

\section{MATERIALS AND METHODS}

\subsection{Materials}

The plasmid pTSY3 containing the $P R C 1$ gene coding for CPD-Y and Saccharomyces cerevisiae SEY2202 (MATa $\Delta p r c 1-\Delta 1$ (LEU2) leu2-3 leu2-112 ura3-52 his4-519) were kindly provided by Dr. TOM STEVENS, University of Oregon, USA. The E. coli strain RZ1032 was a generous gift from Dr. Thomas A. Kunkel, National Institute of Environmental Health Sciences, USA. The E. coli strains JM101 (6) and ED8654 (7) and the M13mp8-derivative G42 (14) were from house collections. The Controlled Pore Glass (CPG) support, 500 A pores, particle size $125-177 \mu$ was from Pierce, USA, and kiesel gel 60 plates DC-Alufolien from Merck Co., FRG. Restriction endonucleases, T4 DNA ligase, DNA polymerase I (Klenow fragment), calf intestinal phosphatase, T4 polynucleotide kinase, 2'-deoxyribonucleotide triphosphates, adenosine triphosphate, M13 sequenc- ing primer 5'-d(TTCCAGTCACGACTG)-3' were obtained from Boehringer Mannheim, FRG. 2'3'-dideoxyribonucleotide triphosphates were obtained from P-L Biochemicals, USA. $\left[\alpha{ }^{32} \mathrm{P}\right] \mathrm{dATP}(>800 \mathrm{Ci} / \mathrm{mmol})$ and $\left[\gamma^{-{ }^{32}} \mathrm{P}\right]$ ATP ( $>7000 \mathrm{Ci} / \mathrm{mmol}$ ) were from New England Nuclear, USA. Nitrocellulose filters were from Schleicher \& Schuell, FRG. Trizma base, Mes, Hepes, DTT and agarose were from Sigma, USA. Phenylglyoxal monohydrate was from Janssen Chimica, Belgium. FA-Phe-OMe was from Bachem, Switzerland, and the following compounds were synthesized as previously described: FA-Phe-Val- $\mathrm{NH}_{2}$, FA-Phe- $\mathrm{NH}_{2}$, FAPhe-Gly- $\mathrm{NH}_{2}$, FA-Phe-OEt, FA-Ala-OBzl, FAPhe-Leu-OH, FA-Phe-Gly-OH, FA-Phe-Ala$\mathrm{OH}$ (1). All other chemicals and solvents were of analytical purity.

\subsection{Methods}

\subsubsection{Synthesis of oligodeoxyribonucleotide}

Base protected 5'-(dimethoxytrityl)-2'-deoxynucleosides were prepared as described by $\mathrm{T} I$ et al. (12), and chloro-2-cyanoethyl-(N,N-diisopropylamino) phosphine as described by SINHA et al. (10). The corresponding phosphoramidites were prepared by dissolving the protected nucleoside $(3 \mathrm{mmol})$ in a mixture of anhydrous dichloromethane $(20 \mathrm{ml})$ and ethyldiisopropylamine $(2 \mathrm{ml})$ and adding chloro-2-cyanoethyl(N,N-diisopropylamino)phosphine $(1.3 \mathrm{ml}$, $6 \mathrm{mmol}$ ). After $30 \mathrm{~min}$ of stirring at room temperature, the reaction mixture was poured into $100 \mathrm{ml}$ of $5 \%$ aqueous $\mathrm{NaHCO}_{3}$ and extracted twice with $100 \mathrm{ml}$ of dichloromethane. After evaporation, the phosphoramidite was applied to a silica gel column, and eluted with ethyl acetate:dichloromethane:triethylamine (45:45:10). The resulting phosphoramidite derivatives were used for oligonucleotide synthesis on a derivatized CPG-support (11). All steps were carried out on a manual Omnifit DNA synthesis apparatus and the flow rate was maintained at $1 \mathrm{ml} \cdot \mathrm{min}^{-1}$ except during the coupling step, at which the flow was stopped for 5 min.

For one addition cycle $0.25 \mathrm{ml} 0.1 \mathrm{M}$-phosphoramidite was used for the coupling reaction together with $0.3 \mathrm{ml} 0.4 \mathrm{M}$-tetrazole in $\mathrm{CH}_{3} \mathrm{CN}$. 
Subsequently, oxidation and capping of the product were carried out using $0.1 \mathrm{M}-\mathrm{I}_{2}$ in tetrahydrofuran:lutidine:water $(80: 20: 10)$ for half a minute and $\mathrm{CH}_{3} \mathrm{CN}$ :lutidine: $\mathrm{Ac}_{2} \mathrm{O}: \mathrm{N}$ methylimidazole (15:3:3:1) for $1 \mathrm{~min}$., respectively. Finally, detritylation was performed in $\mathrm{ClCH}_{2} \mathrm{CH}_{2} \mathrm{Cl}$ for $2 \mathrm{~min}$ by $3 \%$ dichloroacetic acid. Between the various reaction steps the column was washed with $\mathrm{CH}_{3} \mathrm{CN}$ and just before the detritylation an additional wash with $\mathrm{ClCH}_{2} \mathrm{CH}_{2} \mathrm{Cl}$ was carried out. After 19 addition cycles the oligonucleotide was 5'-acylated and treated with concentrated ammonia, first for 15 min at room temperature, then at $55{ }^{\circ} \mathrm{C}$ overnight. The oligonucleotide was purified by thin-layer :chromatography on kiesel gel 60 plates eluted with n-propanol:conc. ammonia:water $(55: 35: 10)$. The homogeneity of the final product was confirmed by HPLC analysis on Lichrosorb $10 \mu \mathrm{NH}_{2}$ (Hibar Fertigsäule RT 250-4, Merck Co., FRG). Elution was performed using a linear gradient, starting with buffer $\mathrm{A}\left(0.005 \mathrm{M}-\mathrm{KH}_{2} \mathrm{PO}_{4}\right.$ in $15 \% \mathrm{CH}_{3} \mathrm{CN}$, pH $6.0)$ applying $2 \%$ per min of buffer $\mathrm{B}(0.75$ $\mathrm{M}-\mathrm{KH}_{2} \mathrm{PO}_{4}$ in $15 \% \mathrm{CH}_{3} \mathrm{CN}, \mathrm{pH} 6.0$ ).

\subsubsection{In vitro mutagenesis}

Cloning procedures and in vitro mutagenesis were carried out essentially as described by WiNTHER et al. (14) with the exception that a uracil containing template prepared as described by KUNKEL (5), was used. The method of KUNKEL makes use of a template, prepared by standard procedures, which after growth on RZ1032 (ung- dut') contains several uracil residues in place of thymine, and yet has a normal coding potential for in vitro reactions. The deficiency of this strain in the product of the $d u t$ gene, dUTP-ase, results in an increased cellular level of dUTP, which increases the probability of incorporation of dUTP in DNA. Uracil, once incorporated into DNA, is not removed due to a deficiency of uracil glycosylase, the product of the ung gene. In the heteroduplex formed after primer extension and ligation, the template strand contains uracil bases. Upon transformation of a wild type $u n g^{+}$ $d u t^{+}$host, the uracil bases are removed, creating apyrimidinic sites in the wild type strand. This increases the frequency of mutants significantly (5, J.R. WINTHER et al., in preparation).

The screening for mutants was carried out by hybridization at room temperature $\left(22^{\circ} \mathrm{C}\right)$ followed by washes in six fold SSC at $22^{\circ} \mathrm{C}, 37^{\circ} \mathrm{C}$, $58^{\circ} \mathrm{C}$, and $66^{\circ} \mathrm{C}$, respectively.

\subsubsection{Isolation and characterization of Arg-398-CPD-Y}

Arg-398-CPD-Y was isolated and purified by affinity chromatography as described for wild type CPD-Y (4). The purification was monitored by assays towards $0.3 \mathrm{mM}$ FA-Phe-OMe as described in ref. 1 . The purity of the resulting enzyme was ascertained by SDS polyacrylamide gel electrophoresis on $1 \mathrm{~mm}$ thick $7.5 \%$ gel slabs in an SDS-phosphate continuous buffer system (13). The amino acid composition was determined after acid hydrolysis for $24 \mathrm{~h}$ using a Durrum D500 amino acid analyser.

\subsubsection{Stability of Arg-398-CPD-Y}

The thermal stability of Arg-398-CPD-Y was investigated by incubation in $50 \mathrm{~mm}-\mathrm{Mes}, 1$ mM-EDTA, pH 6.5 at $55^{\circ} \mathrm{C}$ using a concentration of $0.38 \mathrm{mg} \cdot \mathrm{ml}^{-1}$. The activity towards FA-Phe-OMe was followed as a function of time and the assays were performed in the same buffer as the incubation. The stabilities at different $\mathrm{pH}$ values were measured by incubating the enzyme at $25{ }^{\circ} \mathrm{C}$ at a concentration of 0.18 $\mathrm{mg} \cdot \mathrm{ml}^{-1}$ in the following buffers: $50 \mathrm{mM}-\mathrm{Mes}, 1$ mM-EDTA, pH 5.0; 50 mM-Hepes, 1 mM-EDTA, pH 7.5; 50 mM-2-amino-2-methyl-propanediol, 1 mM-EDTA, pH 9.0; and 50 mM-cyclohexylaminopropane sulfonic acid (CAPS), 1 mM-EDTA, pH 10.0. The activity towards FAPhe-OMe was followed as a function of time and the assays were performed in the same buffer as the incubation.

\subsubsection{Enzymatic properties of Arg-398-CPD-Y}

The kinetic constants for the hydrolysis of various FA-peptide and ester substrates by Arg398-CPD-Y were determined from LineweaverBurk plots. Such determinations were not possible with peptide amides due to their low solubil- 
ity and in these cases $\mathrm{k}_{\text {cal }} / \mathrm{K}_{\mathrm{m}}$-values were determined by following the hydrolysis to completion at a single concentration of substrate and using the integrated form of the Michaelis-Menten equation (9). Hydrolysis rates were determined spectrophotometrically at $329-358 \mathrm{~nm}$ and 25 ${ }^{\circ} \mathrm{C}$. Ester and amide substrates were assayed in $50 \mathrm{~mm}$-Hepes, $1 \mathrm{~mm}$-EDTA, pH 7.5 whereas peptide substrates were assayed in $50 \mathrm{~mm}$-Mes, 1 mM-EDTA, pH 6.5.

\section{2:2.6. Chemical modification with phenylglyoxal}

Modification of Arg-398-CPD-Y was carried out in $7.5 \mathrm{~mm}-\mathrm{NaH}_{2} \mathrm{PO}_{4}, 0.11 \mathrm{M}-\mathrm{NaCl}, \mathrm{pH} 7.5$ at room temperature using an enzyme concentration of $0.475 \mathrm{mg} \cdot \mathrm{ml}^{-1}$. The reagent concentration used was $0.15 \mathrm{M}$.

\section{RESULTS}

The Met-398 to Arg-398 mutation in CPD-Y was accomplished using the uracil containing ssDNA prepared from G42 $2^{u}$ phages grown on RZ1032 and a 19-mer oligonucleotide of the sequence 5'-d(GGCCACAGGGTTCCATT TG)-3'. This oligonucleotide is complementary to the DNA sequence 19 bases downstream of the first nucleotide of the Gly-396 codon, but contains a single G-A mismatch indicated with (*). After annealing of these two components, extension and ligation by DNA polymerase I (Klenow fragment) and T4 DNA ligase, the reaction mixture containing the heteroduplex was used to transform competent JM101 (ung ${ }^{+}$). In this strain a selection in favor of the DNA syṇthesized in vitro, containing the desired mutation, but no uracil, took place. Five phage plaques were obtained which contained either the complement of the methionine codon (ATG) or that of the introduced arginine codon (AGG). One of these was identified as a mutant by dot-blot hybridization screening and the presence of the mutation was confirmed by chain termination sequencing. Replicative form DNA of the mutant phage was digested with PvuII and BglII and a $800 \mathrm{bp}$ fragment containing the subcloned region of $P R C l$ was isolated and reintroduced into the plasmid pTSY3. A plasmid containing the mutation was identified and used to transform S. cerevisiae strain SEY2202 which contains a deletion in the $P R C l$ gene. The yeast strain was grown to saturation in a synthetic complete medium free of uracil. From the resulting $142 \mathrm{~g}$ of plasmid containing yeast cells $8.6 \mathrm{mg}$ homogeneous Arg-398-CPD-Y was isolated by affinity chromatography. Its specific activity towards FA-Phe-OMe was 10 $\mu$ moles $\cdot \mathrm{min}^{-1} \cdot \mathrm{mg}^{-1}$ and $31 \%$ of the activity was recovered. SDS gel electrophoresis indicated that the enzyme was homogeneous with a molecular weight identical to that of CPD-Y $(64,000)$. The amino acid analysis indicated that the methionine content had decreased from 4.8 to 3.8 residues per mole while the arginine content had increased from 9.1 to 9.8 residues per mole consistent with the exchange of a single methionyl residue with an arginyl residue.

The stability of Arg-398-CPD-Y at different $\mathrm{pH}$ values was compared with that of native CPD-Y and of the alkylated derivatives (1). The inactivations were apparently first order reactions, characterized by the half-lives listed in Table I. At pH 5.0 and 7.5 no inactivation was seen, but at the higher $\mathrm{pH}$ values all derivatives exhibited a lower stability than CPD-Y. At $55^{\circ} \mathrm{C}$ CPD-Y and the derivatives were inactivated in

Table I. Stability of CPD-Y, IAA-CPD-Y, PAB-CPD-Y, and Arg-398-CPD-Y at high pH values.

\begin{tabular}{lllll}
\hline $\mathrm{pH}$ & CPD-Y & IAA-CPD-Y & PAB-CPD-Y & Arg-398-CPD-Y \\
\hline 9.0 & 420 & 90 & 240 & 130 \\
\hline 10.0 & 60 & 10 & 30 & 10 \\
\hline
\end{tabular}

Half lives (in minutes) of apparent first order inactivations.

The inactivations were performed at $25^{\circ} \mathrm{C}$ as described in section 2.2 .4 . 
Table II. Thermostability at $55^{\circ} \mathrm{C}$ of CPD-Y, alkylated derivatives, and mutant enzymes.

\begin{tabular}{ll}
\hline CPD-Y & 36 \\
\hline IAA-CPD-Y & 10 \\
\hline PAB-CPD-Y & 25 \\
\hline Arg-398-CPD-Y & 20 \\
\hline Leu-398-CPD-Y & 12 \\
\hline
\end{tabular}

Half-lives (in minutes) of apparent first order inactivations at $\mathrm{pH} 6.5$.

Assay conditions as described in section 2.2.4 apparent first order reactions with the half-lives listed in Table II. The mutant enzymes and the alkylated derivatives are all less stable than CPD-Y, suggesting that Met-398 is important for maintenance of the tertiary structure.

Since the amino acid occupying position 398 is part of the $S_{1}$ binding site, Arg-398-CPD-Y was kinetically characterized using a series of FA-ester, FA-peptide, and FA-amide substrates with different groups at the $P_{1}^{\prime}$ position. The results in Table III show that Arg-398-CPD-Y hydrolyses all substrates with lower $\mathrm{k}_{\mathrm{ca}} / \mathrm{K}_{\mathrm{m}}$ values than does CPD-Y. This decrease, which is mostly due to reduced $k_{\text {cat }}$ values, is more pronounced for substrates with bulky leaving groups than for those with small leaving groups, i.e., -Leu-OH as compared with -Gly-OH, -Val-

Table III. Kinetic parameters for the hydrolysis of ester, peptide, and amide substrates with Arg-398-CPD-Y, IAA-CPD-Y, and CPD-Y.

\begin{tabular}{|c|c|c|c|c|}
\hline Substrate & enzyme & $\begin{array}{l}\mathrm{k}_{\mathrm{cat}} \\
\left(\min ^{-1}\right)\end{array}$ & $\begin{array}{l}\mathrm{K}_{\mathrm{m}} \\
(\mathrm{mM})\end{array}$ & $\begin{array}{l}\mathbf{k}_{\mathrm{cat}} / \mathrm{K}_{\mathrm{m}} \\
\left(\mathrm{min}^{-1} \cdot \mathrm{mM}^{-1}\right)\end{array}$ \\
\hline \multirow{3}{*}{ FA-Phe-OMe } & Arg-398-CPD-Y & 1330 & 0.40 & 3300 \\
\hline & IAA-CPD-Y & 6300 & 0.87 & 7200 \\
\hline & CPD-Y & 11000 & 0.39 & 28000 \\
\hline \multirow[t]{3}{*}{ FA-Phe-OEt } & Arg-398-CPD-Y & 1390 & 0.095 & 15000 \\
\hline & IAA-CPD-Y & 8200 & 0.10 & 82000 \\
\hline & CPD-Y & 11000 & 0.059 & 190000 \\
\hline \multirow[t]{3}{*}{ FA-Ala-OBzl } & Arg-398-CPD-Y & 1700 & 0.50 & 3500 \\
\hline & IAA-CPD-Y & 3300 & 0.36 & 9700 \\
\hline & CPD-Y & 9100 & 0.054 & 170000 \\
\hline \multirow[t]{3}{*}{ FA-Phe-Leu-OH } & Arg-398-CPD-Y & 9 & 0.10 & 90 \\
\hline & IAA-CPD-Y & 25 & 0.080 & 320 \\
\hline & CPD-Y & 4900 & 0.021 & 230000 \\
\hline \multirow{3}{*}{ FA-Phe-Gly- $-\mathrm{OH}$} & Arg-398-CPD-Y & 200 & 4.3 & 46 \\
\hline & IAA-CPD-Y & 190 & 8.7 & 22 \\
\hline & CPD-Y & 5800 & 5.4 & 1100 \\
\hline \multirow[t]{3}{*}{ FA-Phe- $\mathrm{NH}_{2}$} & Arg-398-CPD-Y & & & 6 \\
\hline & IAA-CPD-Y & & & 17 \\
\hline & CPD-Y & & & 89 \\
\hline \multirow[t]{3}{*}{ FA-Phe-Val-NH ${ }_{2}$} & Arg-398-CPD-Y & & & 210 \\
\hline & IAA-CPD-Y & & & 360 \\
\hline & CPD-Y & & & 6200 \\
\hline \multirow{3}{*}{ FA-Phe-Gly- $\mathrm{NH}_{2}$} & Arg-398-CPD-Y & & & 43 \\
\hline & IAA-CPD-Y & & & 21 \\
\hline & CPD-Y & & & 160 \\
\hline
\end{tabular}

Assay conditions as described in section 2.2.5. 
$\mathrm{NH}_{2}$ as compared with - Gly- $\mathrm{NH}_{2}$, and - $\mathrm{OBzl}$ as compared with -OEt and -OMe.

A characterization of IAA-CPD-Y carried out using the same series of substrates (1) shows that the $k_{\text {cat }}$ and $K_{m}$ values obtained with this enzyme are of the same order of magnitude as those obtained with Arg-398-CPD-Y.

The influence of ionic strength of the assay medium on Arg-398-CPD-Y has been compared with that on wild-type CPD-Y and IAACPD-Y by adding $\mathrm{NaCl}$ up to $0.5 \mathrm{M}$. At this concentration the activities of all three enzymes towards FA-Phe-OMe, FA-Ala-OBzl, and FAPhe-Ala-OH were $120 \%, 80 \%$, and $60 \%$, respectively, of those measured without $\mathrm{NaCl}$, and hence no specific effect of ionic strength on Arg-398-CPD-Y was observed.

It was investigated whether treatment of CPD-Y and Arg-398-CPD-Y with phenylglyoxal, a reagent known to modify arginyl residues, affected their activities differently. After reaction for two hours the activities of Arg-398CPD-Y towards FA-Phe-OMe and FA-Phe-Leu$\mathrm{OH}$ had both decreased to approximately $50 \%$. However, this closely paralleled the influence of phenylglyoxal on wild type CPD-Y, and thus the introduction of Arg-398 has not increased the sensitivity of the enzyme towards this reagent in contrast to what might be expected if the Arg398 was freely exposed in the $S_{1}^{\prime}$ binding site.

\section{DISCUSSION}

Chemical modifications of the methionyl residue in position 398 of CPD-Y has previously indicated that this residue is a constituent of the $S_{1}$ binding site of the enzyme $(1,2,3)$. This presumed role of Met-398 was confirmed by investigations of the enzymatic properties of a CPD-Y in which Met-398 was replaced by a leucine residue by means of site-directed mutagenesis (14). In the present paper the function of Met-398 has been further elucidated by the use of site-directed mutagenesis to introduce a positively charged arginyl residue at position 398 . CPD-Y derivatives with positive charges in this position have previously been prepared by alkylation with iodoacetamide and by reaction with phenacylbromide. In Figure 1 the structure of these derivatives are compared.

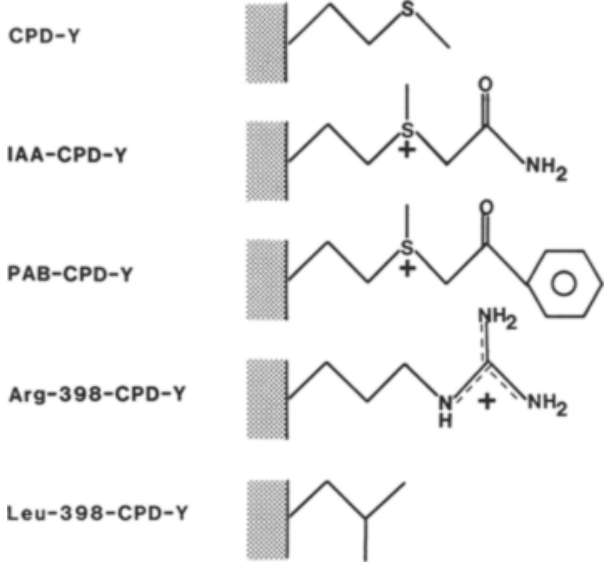

Figure 1. Schematic representation of the structures of the side-chains at position 398 in CPD-Y, IAA-CPDY, PAB-CPD-Y, Arg-398-CPD-Y, and Leu-398-CPD$Y$.

The enzyme, which contains an arginyl residue at position 398 , exhibits reduced $k_{\text {cat }} / K_{m}$ values for the hydrolysis of substrates with blocked C-terminus, i.e., ester and amide substrates, and in particular for those with bulky groups in the $\mathrm{P}_{\mathrm{i}}$ position. This effect is due to both an increase in $\mathrm{K}_{\mathrm{m}}$ and a decrease in $\mathrm{k}_{\text {cat }}$. For peptide substrates $k_{\mathrm{cat}} / \mathrm{K}_{\mathrm{m}}$ is even more reduced but in this case it is primarily due to a drastic decrease in $\mathrm{k}_{\text {cat }}$ and it is much less dependent on the bulkiness of the group occupying the $\mathrm{P}_{i}$ position. These changes are qualitatively similar to those obtained with the enzyme in which Met-398 has been alkylated with iodoacetamide, IAA-CPD-Y. This is consistent with the acetamide methionyl sulfonium group being structurally reminiscent of the arginyl sidechain, both groups containing an aliphatic chain and a positive charge.

The additional presence of a bulky phenyl group together with the sulfonium ion, as in the enzyme modified with phenacylbromide (PABCPD-Y), strongly influences the activities towards ester and amide substrates: the $\mathrm{k}_{\text {cat }} / \mathrm{K}_{\mathrm{m}}$ values for the hydrolysis of substrates with bulky leaving groups, e.g., -OBzl and - Val- $\mathrm{NH}_{2}$ are further reduced as compared with Arg-398CPD-Y and IAA-CPD-Y, whereas the values for those with non-bulky leaving groups, i.e., -OMe 
and $-\mathrm{NH}_{2}$, are drastically increased as compared with IAA-CPD-Y and Arg-398-CPD-Y and to a level which markedly exceeds that of unmodified wild type CPD-Y (1). However, the phenyl group in PAB-CPD-Y appears to have only insignificant influence on the low $\mathrm{k}_{\text {cat }}$ values for the hydrolysis of peptide substrates. This suggests that the positive charge common to both these alkylated derivatives and to Arg-398-CPD$\mathrm{Y}$ is responsible for the low $\boldsymbol{k}_{\text {cat }}$ values.

It is not possible, on the basis of the present data, to explain in detail how the positive charge at Arg-398 exerts its adverse influence on $\mathrm{k}_{\text {cat }}$ for peptide hydrolysis. However, the absence of effects of phenylglyoxal and of the ionic strength of the assay medium would suggest that the charged guanido group is not in direct contact with the substrate. It is possible that Arg-398 and, by inference, the positive charge of the sulfonium derivative, has complexed with another group in the enzyme or, alternatively, that Arg-398 through a conformational change has been displaced away from the $S_{1}$ binding site, such that its interaction with anions and phenylglyoxal need not influence its activities. The observation that the stability of Arg-398-CPD-Y is higher than that of Leu-398-CPD-Y provides some support for these explanations, since a positive charge located in the hydrophobic environment of the $S_{1}$ binding site presumably would destabilize the enzyme more than the conservative replacement of the methionyl residue with a leucyl residue.

\section{ACKNOWLEDGEMENTS}

Professor MARTIN OTTESEN is thanked for his interest and encouragement during this work and for critically revising the manuscript. Dr. TOM STEvens, Institute of Molecular Biology, University of Oregon, USA, is acknowledged for his donation of the pTSY3 plasmid, the S. cerevisiae strain SEY2202 and the complete DNA-sequence of PRC1. Dr. THOMAS A. KUNKEL, National Institute of Environmental Health Sciences, USA, is thanked for providing the E. coli strain RZ1032.

\section{REFERENCES}

1. BredDaM, K.: Chemically modified carboxypeptidase $Y$ with increased amidase activity. Carlsberg Res. Commun. 49, 535-554 (1984)

2. BREDDAM, K.: Modification of amino acid residues in the $S_{1}$ binding site of carboxypeptidase $Y$. Carlsberg Res. Commun. 49, 627-638 (1984)

3. BREDDAM, K. \& I. SVENDSEN: Identification of methionyl and cysteinyl residues in the substrate binding site of carboxypeptidase Y. Carlsberg Res. Commun. 49, 639-645 (1984)

4. Johansen, J. T., K. Breddam \& M. Ottesen: Isolation of carboxypeptidase $\mathrm{Y}$ by affinity chromatography. Carlsberg Res. Commun. 41, 1-14 (1976)

5. KUNKEL, T. A.: Rapid and efficient site-specific mutagenesis without phenotypic selection. Proc. Natl. Acad. Sci. USA 82, 488-492 (1985)

6. Messing,J.: A multi-purpose cloning system based on the single-stranded DNA bacteriophage M13. Recombinant DNA Tech. Bull., NIH publication No. 79-99, 2, 43-48 (1979)

7. Murray, N. E., W. J. Brammar \& K. Murray: Lambdoid phages that simplify recovery of in vitro recombinants. Mol. Gen. Genet. 150, 53-61 (1977)

8. SCHECHTER, I.\& A. BERGER: On the size of the active site of proteases. I. Papain. Biochem. Biophys. Res. Commun. 27, 157-167 (1967)

9. SEGEL, I.: Biochemical calculations. John Wiley \& Sons, New York, pp 393-395 (1968)

10. Sinha, N. D., J. Biernat, J. McManus \& H. Köster: Polymer support oligonucleotide synthesis XVIII: use of $\beta$-cyanoethyl-N,N-dialkylamino-/N-morpholino phosphoramidite of deoxynucleosides for the synthesis of DNA fragments simplifying deprotection and isolation of the final product. Nucleic Acids Res., 12, 4539-4557 (1984)

11. Sproat, B.S.\& M. J.GaIt: Oligonucletide synthesis, a practical approach. Gait, M. J. (ed), 83-1 15, IRL Press, Oxford, Washington, D. C. (1984)

12. Ti, G. S., B. L. Gaffney \& R. A. Jones: Transient protection: Efficient one-flask syntheses of protected deoxynucleosides. J. Am. Chem. Soc. 104, 1316-1319 (1982)

13. Weber, K., J. R. Pringle \& M. Osborne: Measurement of molecular weights by electrophoresis on SDS-acrylamide-gel. Methods Enzymol. 26, 3-27 (1972)

14. Winther, J. R., M. C. Kielland-Brandt \& K. BREDDAM: Increased hydrophobicity of the $S_{1}$; binding site in carboxypeptidase $Y$ obtained by site-directed mutagenesis. Carlsberg Res. Commun. 50, 273-284 (1985)

Accepted by H. KLENOw 